\title{
A ARBITRABILIDADE OBJETIVA DOS CONFLITOS ENVOLVENDO O PODER PÚBLICO E AS PERSPECTIVAS DA ARBITRAGEM TRIBUTÁRLA NO BRASIL
}

\author{
THE OBJECTIVE ARBITRABILITY OF CONFLICTS \\ CONCERNING PUBLIC POWER AND THE PROSPECTS OF TAX \\ ARBITRATION IN BRAZIL \\ Carlos Henrique Machado ${ }^{1}$ \\ Ricardo Soares Stersi dos Santos ${ }^{1}$ \\ João Ricardo Catarino
}

É você, Que ama o passado, E que não vê Que o novo sempre vem

(Como Nossos Pais, Elis Regina)

\begin{abstract}
Recebido em: 31/10/2017 Aceito em: 02/06/2018

oab18157@gmail.com rstersi@hotmail.com jcatarino@iscsp.ulisboa.pt
\end{abstract}

Resumo: O presente artigo propõe uma reflexão sobre as perspectivas da arbitragem tributária no Brasil, a partir de experiências exitosas em relação os métodos adequados de solução de conflitos em geral, que avançam no ordenamento jurídico pátrio. Retrata-se o panorama atual da Justiça no Brasil, demonstrando-se a necessidade premente de superação daquilo que se convencionou chamar de cultura da sentença. Nesse sentido, buscando demonstrar a superação de barreiras como a arbitrabilidade objetiva em relação aos conflitos envolvendo a Administração Pública, o artigo discute um modelo de solução de conflitos fiscais desapegado de axiomas e dogmas tradicionais, com aportes na experiência do Direito de Portugal.

Palavras-chave: Arbitrabilidade objetiva. Arbitragem. Cultura da sentença. Métodos adequados de solução de conflitos. Tributário.

\begin{abstract}
The present paper proposes a reflection on the prospects of tax arbitration in Brazil, based on sucessful experiences regarding the appropriate conflict resolution methods in general, which advance in domestic legal order. Brazil's current justice panorama is portrayed, showing the urgent need to overcome what has been conventionally called sentence culture. In this sense, looking to demonstrate the overcoming of barriers such as objective arbitrability concerning conflicts that involve Public Administration, this paper discusses a model of fiscal conflict resolution detached from traditional axioms and dogmas, with contributions from the legal experience in Portugal.
\end{abstract}

Keywords: Objective arbitrability. Arbitration. Sentence culture. Appropriate conflict resolution methods. Tributary.

\section{INTRODUÇÃO}

A discussão relativa aos métodos adequados de solução de conflitos em uma Sociedade não deve ser compreendida como um fenômeno exatamente contemporâneo. A administração dos conflitos sociais e jurídicos é uma necessidade que permeia a própria existência da vida em Sociedade, de maneira que cada grupo social estabelece os mecanismos próprios para promover a pacificação social.

\footnotetext{
${ }^{1}$ Universidade Federal de Santa Catarina - UFSC - Florianópolis - Santa Catarina - Brasil

${ }^{2}$ Universidade de Lisboa - ULisboa - Lisboa - Portugal
} 
Nesse sentido, os métodos de administração dos conflitos jurídicos são criações sociais e refletem a "cultura" de dado grupo social, no que tange às formas admitidas pelo próprio grupo, para a gestão dos conflitos em determinado momento histórico. O estabelecimento de uma "cultura" diferenciada em cada grupo social, em relação aos comportamentos adotados para solucionar os seus conflitos, é demonstrado por Galtung (2006, p. 191-202) ao discorrer sobre os conflitos separatistas na Espanha, envolvendo Castela, Catalunha e País Basco.

Enquanto para alguns grupos sociais a utilização da ameaça e da violência privada foi, e ainda é, admitida como método para promover a pacificação social, essa função passou a ser realizada, no Ocidente, pela atuação preponderante do Estado, em especial pelo seu braço Poder Judiciário. No Brasil, especificamente, o predomínio do modelo judicial na administração dos conflitos jurídicos passou a ser designado como "cultura da sentença", que se trata, segundo Watanabe (2007, p. 07), de uma mentalidade forjada nas academias e fortalecida na práxis forense, direcionada à solução adjudicada autoritativamente pelo juiz por meio da sentença.

Desde sempre os meios de resolução de litígios sofreram transformações, com avanços mais ou menos intensos em termos de efetivação das expectativas da Sociedade. O atual paradigma, desse modo, não representa uma novidade. Pelo contrário, pretende-se retomar a busca pelos métodos mais adequados de solução para cada modalidade de conflito. Noutras palavras, efetivar valores constitucionais e promover o amplo acesso à jurisdição.

Recentemente, no Brasil, em especial com o advento da Resolução ㄲo 125, de 29 de novembro de 2010, do Conselho Nacional de Justiça, os métodos adequados de solução de conflitos receberam um impulso importantíssimo, a partir do reconhecimento institucional das próprias estruturas do Poder Judiciário em relação à necessidade de buscar alternativas para os relevantes problemas enfrentados com a adequada prestação da jurisdição. A medida foi acompanhada por alguns avanços legislativos significativos, vivenciando o país, atualmente, um momento de superação da cultura do litígio.

Nesse percurso pela investigação de soluções mais apropriadas para as diferentes modalidades de conflitos, também foram identificados aspectos problemáticos envolvendo a Administração Pública como circunstâncias prejudiciais à efetivação da jurisdição, assim se ampliando alguns espaços para a legitimação dos meios alternativos de pacificação, como a arbitragem. Hoje, superadas em parte as problemáticas que atormentaram a arbitrabilidade das contratações públicas, a questão reaviva-se no âmbito dos passivos tributários.

O intuito do presente texto, sem o propósito de apresentar uma solução categórica para o problema que atinge o sistema processual tributário, busca identificar algumas características desse sistema, além de apresentar os indicadores da tributação brasileira, com a finalidade de melhor compreender os reflexos produzidos no modelo atual de jurisdição. Além disso, pretende também discutir a possibilidade de utilização da arbitragem como mecanismo de administração de certos conflitos relativos às questões tributárias. O método para a abordagem do assunto é o hipotéticodedutivo, com pesquisa bibliográfica, documental e de julgados. 


\section{O RETRATO DA JUSTIÇA NO BRASIL: O PODER JUDICIÁRIO PEDE SOCORRO}

Os números da Justiça no Brasil são alarmantes. Qualquer estudo que se proponha a analisar o custo-benefício do Poder Judiciário para o para cidadão brasileiro certamente chegará a conclusão de que o sistema jurisdicional é demasiadamente custoso e moroso para a sociedade. Segundo Luciano Da Ros (2015, p. 08), existem motivos plausíveis para explicar porque o Brasil precisa de um sistema de justiça mais oneroso do que o de países europeus ou norte-americanos, como, por exemplo, o legado de instituições autoritárias, as incertezas jurídicas derivadas do cenário de sucessivas conjunturas econômicas das décadas de 1980 e 1990, além, principalmente, das abissais desigualdades socioeconômicas existentes.

Conforme evidenciam os indicadores do Conselho Nacional de Justiça, as despesas com a estrutura jurisdicional no Brasil equivalem a 1,3\% do Produto Interno Bruto. Apenas no ano de 2015, os gastos totais com o Poder Judiciário somaram $R \$ 79,2$ bilhões, equivalentes ao custo de $R \$$ 387,56 , por habitante, desembolsado pelos serviços de Justiça. Os gastos com os recursos humanos são responsáveis por $89 \%$ da despesa total (CNJ, 2016, p. 33). Estima-se, por outro lado, que esse percentual seja de somente $0,14 \%$ nos Estados Unidos; na Alemanha, de 0,32\%; enquanto na Argentina; de apenas $0,13 \%$ (DA ROS, 2015, p. 04).

Essa realidade causa ainda mais perplexidade quando se verifica que, no Brasil, existem 8,2 juízes, em média, para cada cem mil habitantes. Nos Estados Unidos, esse número é de 10,8 juízes; já na Argentina, a quantidade aumenta para 11,4 juízes; e na Alemanha, o número de magistrados atinge 24,7. Em suma, o custo do sistema judiciário brasileiro, em termos relativos ao Produto Interno Bruto, é aproximadamente quatro vezes maior que o da Alemanha; é dez vezes superior ao da Argentina. Na Alemanha, no entanto, com muito menos despesas com o Poder Judiciário, há proporcionalmente três vezes mais juízes que no Brasil (DA ROS, 2015, p. 05).

De acordo com o a arquétipo jurisdicional modelado pela Constituição Federal de 1988, o Brasil conta com uma estrutura de 91 Cortes de Justiça: o Supremo Tribunal Federal, quatro Tribunais Superiores (STJ, TST, TSE e STM), vinte e sete Tribunais de Justiça Estaduais, cinco Tribunais Regionais Federais, vinte e quatro Tribunais Regionais do Trabalho, vinte e sete Tribunais Regionais Eleitorais, além de três Tribunais de Justiça Militar Estaduais. Atualmente, existem aproximadamente 17.338 juízes nas estruturas jurisdicionais, equivalentes a 3,8\% de uma força de total trabalho de 451.497 servidores públicos atuantes no sistema de justiça. Um verdadeiro batalhão de pessoas vinculadas ao Poder Judiciário (CNJ, 2016, p. 37). Comparativamente a outros países do mundo, esses quantitativos são elevadíssimos, demonstrando que, no Brasil, não há carência de recursos humanos.

Apenas no ano de 2015, tramitaram pelo Poder Judiciário brasileiro cerca de 102 milhões de processos (CNJ, 2016, p. 42). Durante esse período, mesmo que os índices de produtividade dos magistrados tenham aumentado sensivelmente, o volume de processos judicializados apresentou um crescimento expressivo. A taxa de congestionamento, no ano de 2015 , sofreu uma evolução de $0,5 \%$, atingindo o patamar de 72,2\% (CNJ, 2016, p. 48), ou seja, a cada 100 novas ações ajuizadas, cerca de 72 não foram solucionadas pelo Judiciário.

Revista do Direito [ISSN 1982-9957]. Santa Cruz do Sul, v. 1, n. 54, p. 59-85, jan./abr. 2018. https://online.unisc.br/seer/index.php/direito/index 
Em paralelo, o tempo médio de tramitação dos processos judiciais em curso é relativamente elevado, especialmente na fase de execução, importando o tempo de 08 anos e 11 meses, na Justiça Estadual, e de 7 anos e 9 meses, da Justiça Federal (CNJ, 2016, p. 69). A realidade dos números é emblemática e simboliza que o Judiciário pede socorro. O sistema jurisdicional é absolutamente caro em relação aos demais países do mundo, mas a efetividade do serviço é ainda bastante precária.

O problema agrava-se ainda mais quando objeto das judicializações corresponde a litígios tributários. A Lei de Execuções Fiscais oㅜ 6.830, de 22 de setembro de 1980, tem-se demonstrado absolutamente defasada e ineficiente no Brasil. Menos de 10\% das multas tributárias são quitadas oportunamente, evidenciando uma política fiscal equivocada. Há enormes resistências em avançar no tema da solução adequada de conflitos em matéria tributária, apesar dos instrumentos contenciosos mostrarem-se flagrantemente infrutíferos, olvidando-se, ademais, as experiências bem-sucedidas em países europeus, notadamente em Portugal, com iniciativas exitosas no campo da arbitragem.

De acordo com os levantamentos do Conselho Nacional de Justiça, os processos de execução fiscal representam, aproximadamente, $39 \%$ da totalidade de demandas pendentes no Brasil e $75 \%$ das execuções ativas no Poder Judiciário.

Conforme Morais (2014, p. 729-732), o aumento dos conflitos entre os contribuintes e a Administração deve-se precipuamente a três fatores distintos. O primeiro dos fatores é a atuação "prepotente" da Administração Tributária ao estabelecer um comportamento autoritário em relação ao contribuinte, sempre revestindo de um suposto amparo legal o seu próprio interesse de incremento da arrecadação. Exemplo disso são os processos administrativos tributários, em que a interpretação prófisco impera de forma absoluta. O segundo dos fatores é a complexidade da legislação tributária elaborada, em regra, sem respeito à técnica jurídica e sujeita a modificações frequentes. O terceiro e último dos fatores é a quantidade muito grande de mudanças no sistema tributário, com o abuso das medidas provisórias para a sua realização, o que acaba por gerar uma série de normas incongruentes entre si sempre interpretadas pela própria Administração em seu proveito. A estas Catarino (2009, p. 433 - 450) aduz um vasto conjunto de outras, como a crise dos fatores nucleares da tributação; as excessivas complexidades do sistema tributário e dos modelos de imposto; a instabilidade e crescente opacidade das normas e dos regimes tributários e os problemas derivados da concorrência fiscal internacional, aceitável e prejudicial.

Morais (2014, p. 732;) ainda acrescenta que a crescente litigiosidade entre o Fisco e os contribuintes é o resultado mensurável da preocupação de ambas as partes em obter o melhor resultado econômico possível em suas respectivas atuações: por um lado, a Administração Tributária procura atingir metas de arrecadação por meio da adoção de leis inconstitucionais ou de atos administrativos ilegais; de outro, os contribuintes praticam defraudações e infrações em geral para dirimir o impacto dos tributos em sua vida.

No ano de 2015, havia 28.937.316 execuções tributárias em tramitação, cujos processos apresentaram uma elevada taxa de congestionamento, de 91,9\%, ou seja, a cada 100 processos de execução fiscal em curso, apenas 08 restaram baixados (CNJ, 2016, p. 61-63). Não obstante, o modelo jurisdicional tributário é pernicioso, permitindo uma discussão dos passivos fiscais por vias diferentes, compatíveis e demoradas, como os embargos à execução, o mandado de segurança, as 
ações anulatórias e declaratórias, a exceção de pré-executividade etc., de modo que os direitos e interesses fazendários e, em última análise, os da própria Sociedade, restam manipulados e vilipendiados com facilidade pelos maus pagadores.

\section{A SUPERAÇÃO DA CULTURA DA SENTENÇA NO DIREITO BRASILEIRO}

Desde os momentos primórdios da história registrada das Sociedades, os conflitos sempre estiveram presentes nas mais variadas configurações da manifestação humana. O surgimento dos Estados e da função jurisdicional, como um produto das grandes revoluções que redefiniram as relações sociais modernas, é uma construção histórica que dimana dessa realidade, com o fim de oferecer soluções impositivas aos conflitos intersubjetivos.

O conceito de conflito é um tema debatido, há muitos anos, no âmbito de diversas Ciências, ainda sem conclusões definitivas. Jean-Jacques Rousseau desenvolveu a ideia de que a sociedade corrompe o homem, sendo que a violência é o produto do convívio social (ROUSSEAU, 2013, p. 2629). Max Weber, por sua vez, formulou proposição sobre os conflitos pautada nas relações sociais, reconhecidas a partir de condutas interdependentes e recíprocas que se amoldam. Para ele, uma luta ocorre quando as ações se orientam com o intuito de impor a vontade própria contra a resistência dos parceiros (WEBER, 2015, p. 23). De fato, conforme explica Remo Entelman, os conflitos são apenas uma das modalidades possíveis de relação social, que compõem invariavelmente o cotidiano dos indivíduos, sejam essas relações mais duradouras ou efêmeras. O conflito é a percepção de que o comportamento do outro impede o exercício de uma conduta ou um interesse próprio, uma satisfação individual (ENTELMAN, 2005, p. 49). Inegavelmente, portanto, a abordagem sobre os conflitos exige sempre uma abordagem multidisciplinar, suscetível a soluções diversas e mais adequadas.

Devido ao caráter nocivo dos conflitos, além dos altos custos físicos, emocionais e financeiros resultantes das disputas, as pessoas têm buscado, historicamente, maneiras variadas de resolver as suas desavenças. Sobre o tema, Christopher Moore (1998, p. 19) aduz que os indivíduos, procurando administrar e resolver as suas diferenças, têm tentado desenvolver procedimentos que sejam eficientes e que Ihes permitam satisfazer os seus interesses, minimizando os seus sofrimentos e controlando os gastos desnecessários. Na maioria das disputas, as partes envolvidas possuem a sua disposição diversos mecanismos para reagirem aos seus conflitos ou resolvê-los, sendo que os procedimentos se diferem pela maneira como as questões são direcionadas e definidas, provocando uma gama enorme de resultados diferentes, tanto tangíveis quanto intangíveis. O Direito, em especial, exerce um papel importante, mas também restrito, na administração desses conflitos.

Historicamente, no Brasil, a cultura da sentença sempre foi estimulada, no sentido de prevalecer frequentemente a alternativa da judicialização para a solução dos conflitos. Kazuo Watanabe (2005, p. 986-987) destaca que tal cultura ainda predomina entre nós, apesar do atual sistema processual brasileiro prestigiar, em vários dispositivos, a utilização dos métodos adequados de resolução de conflitos, a exemplo da conciliação, da mediação e da arbitragem. Segundo o Autor, persiste ainda certo preconceito, impulsionado por razões diferentes, contra os mecanismos alternativos de pacificação, potencializado pelos temores de juízes, que enxergam o seu poder 
diminuído diante da desjudicialização, ou simplesmente pela falsa percepção de que a atribuição de conciliar representa uma atividade menos nobre que a de julgar.

Como agravamento dessa cultura monopolizada, Maus (2000, p. 186) faz um retrato do Poder Judiciário como o superego da sociedade órfã. Segundo a Autora, os juízes acabaram se tornando os próprios juízes da lei, investindo-se como sacerdotes-mor de uma nova divindade, o Direito supra positivo, sendo-Ihes confiada a tarefa central de sintetizar toda a heterogeneidade social (MAUS, 2000, p. 186).

No Brasil, de fato, o acesso à justiça é ainda relativamente barato se comparado a outros países do mundo, sobretudo considerando que o custo da jurisdição é subsidiado relevantemente pelo Estado. Em 2015, apenas a Justiça Federal conseguiu arrecadar mais do que as suas próprias despesas, com receitas no valor de $\mathrm{R} \$ 24$ bilhões, equivalentes a um montante 2,4 vezes maior do que os seus gastos (CNJ, 2016, p. 216). Nenhuma outra estrutura do Poder Judiciário obteve receitas superiores aos seus próprios gastos. A Justiça do Trabalho, por exemplo, arrecadou cerca de $R \$ 2,7$ bilhões, montante representativo de apenas $16,3 \%$ das suas despesas (CNJ, 2016, p. 158).

Todo esse cenário perturbador que assola o Poder Judiciário é potencializado ainda mais pela formação acadêmica inadequada dos estudantes de Direito, fundamentalmente voltada às soluções contenciosas de conflitos. Como observam Santos, Pozzatti Jr e Maillart (2014, p. 87), avaliando as grades curriculares de importantes Curso de Direito dos três Estados do Sul do Brasil e do Estado de São Paulo, os futuros operadores do Direito são ensinados e treinados primordialmente para conhecer e aplicar o Direito por meio da forma judicial, cuja formação técnica, em relação aos meios que podem utilizar na administração de conflitos, destaca o ensino e o aprendizado dos processos contenciosos. Atualmente, observam os Autores, a carga horária das disciplinas de Processo, somada com as cargas do estágio supervisionado, possuem algo em torno de um quinto a um quarto da carga horária total para a integralização dos cursos jurídicos. Para eles, fica claro que as cargas horárias ínfimas atribuídas às disciplinas voltadas aos métodos adequados de solução de conflitos sugerem um viés predominantemente teórico, sem qualquer complementação prática (obrigatória ou eletiva), limitando a qualificação dos operadores do Direito que deixam os Cursos Jurídicos (SAN-TOS, POZZATTI JR., MAILLART, 2014 p. 88).

Os indicadores são emblemáticos e demonstram que a formação dos profissionais de Direito não os prepara para atuarem num modelo de jurisdição consensual, com a capacitação e a qualificação suficientes para lidar com os instrumentos adequados de solução de conflitos.

Wolkmer (2001, p. 88), discorrendo sobre a trajetória da cultura jurídica no Brasil, destaca que a ênfase da tradição de legalidade, estimulada pelo monopólio da produção normativa estatal, foi traço significativo para a formação dogmática integrada no ensino e na aplicação do Direito, como também na prolongada influência formalista sobre gerações de advogados, juristas e professores. Segundo o Autor, repensar criticamente o paradigma da juridicidade estatal brasileira impõe a tarefa de desmistificar a tradição hegemônica de uma cultura marcada pela visão formalista do Direito, que reproduz um saber jurídico meramente retórico, cuja superação é de difícil consecução, porquanto é justificadora e mantenedora do sistema político, expondo a percepção do Direito unicamente como um instrumento de poder (WOLKMER, 2001, p. 89). 
Aludindo Boaventura de Sousa Santos (obter a fonte primária para não fazer citação apud), observa Ana Carolina Squadri Santanna (2013, p. 4-5) que a retomada da democracia no Brasil, alavancada por importantes avanços legislativos, alçou o Poder Judiciário a um patamar de protagonismo no cenário republicano, com o forte empoderamento das estruturas jurisdicionais, reconhecidas pelo seu papel de vanguarda na garantia dos direitos do cidadão. Como consequência dessa expansão e do fortalecimento do Poder Judiciário, acompanhado do incremento da máquina estatal com a contratação de servidores públicos, os magistrados passaram a deter maior legitimidade perante a sociedade, construindo-se expectativas fundadas em torno do sistema judicial, como se pudesse solucionar todas as mazelas e todos os descasos do sistema político-econômico.

Kazuo Watanabe (2005, p. 688), no entanto, relembra que essa busca mais intensa pelo Poder Judiciário, curiosamente, nem sempre foi assim. Em época mais remota, pelo contrário, durante a vigência da Constituição do Império de 1824, havia previsão proibitiva expressa de buscar o sistema jurisdicional, dispondo o seu art. 161 que "sem se fazer constar que se tem intentado o meio da reconciliação, não começará processo algum".

É cediço, por outro lado, que os meios alternativos (ou adequados) de solução de conflitos vêm ocupando um grande espaço no cenário da pacificação social. Não se pode negar que a cultura da sentença é claramente fruto da ausência de conhecimento e acesso aos mecanismos apropriados de composição, que ainda carecem de maiores estímulos. Sem desconhecer ou negar que a justiça estatal funciona e é sim muito útil em inúmeros casos, impossível não reconhecer, igualmente, que não é solução apropriada em diversas outras situações. É fundamental, portanto, ajustar cada modalidade de conflito ao respectivo meio jurisdicional subjacente, assegurando e promovendo, assim, um verdadeiro e amplo acesso à justiça a todos os cidadãos.

Nessa linha, sem deixar de reconhecer a moderna vocação da justiça estatal para oferecer múltiplas e diferenciadas formas para a tutela jurisdicional, Grinover (2016, p. 61-62) afirma que não existe um caminho único pelo qual se procura oferecer solução para todas as espécies de conflitos, avançando no mundo inteiro, inclusive no Brasil, diferentes métodos adequados de resolução. Segundo a Autora, a percepção de uma tutela adequada para cada modalidade específica de conflito transformou o modo de enxergar a arbitragem, a conciliação e a mediação, que, de métodos sucedâneos, equivalentes ou meramente alternativos à jurisdição estatal, assumiram um status de instrumentos mais adequados de solução de determinados conflitos.

Caminhando nesse rumo, justamente, a partir do reconhecimento dessa cultura de sentença enraizada na sociedade brasileira, capaz de elevar significativamente o número de ações propostas perante o Poder Judiciário nos últimos anos, o Conselho Nacional de Justiça (CNJ) tratou de editar a Resolução $n^{\circ}$ 125, de 2010, implementando a "Política Judiciária Nacional de tratamento adequado dos conflitos de interesses no âmbito do Poder Judiciário". A medida significou um passo importante para a promoção da cultura do consenso, estabelecendo o marco histórico de uma nova identidade jurisdicional no Brasil.

Essa nova realidade encontra-se alicerçada numa cultura de lealdade, de ética e de transparência, que pretende estabelecer uma ruptura com a tradição jurídica estritamente belicosa e maniqueísta, ressignificando a definição das disputas e recolocando os conflitos num patamar de 
ganha-ganha, ao invés do ganha-perde. Pretende-se, dessa maneira, uma composição de conflitos com foco maior em atitudes compreensivas e preventivas, em lugar de ações repressivas; enfim, trata-se de uma nova cultura de afirmação da cidadania.

\section{OS MÉTOdOS ALTERNATIVOS (OU ADEQUADOS) DE SOLUÇÃO DE CONFLITOS E OS AVANÇOS DA ARBITRAGEM NO BRASIL}

Nos últimos anos houve um avanço inegável e significativo dos chamados métodos adequados de resolução de conflitos no Brasil, especialmente nas duas últimas décadas. A receptividade de novos meios de pacificação pela sociedade brasileira é bastante evidente, potencializada pela ineficiência e morosidade do Poder Judiciário.

Com o advento da Constituição de 1988, em especial, houve um reconhecimento muito expressivo de novos direitos, sucedido por importantes avanços jurídico-legislativos, levando ao exagero o movimento da judicialização. Tal conjuntura gerou uma mutação do sistema jurisdicional estatal num modelo completamente esgotado, atualmente afogado em mais de 100 milhões de processos em tramitação.

Numa visão contemporânea, a ideia de jurisdição suplantou os conceitos clássicos da teoria geral do processo, transcendendo ao modelo de resolução de conflitos prestado unicamente pelas instituições públicas, com exclusividade. Nesse sentido, exatamente, Ada Pellegrini Grinover (2016, p. 20) destaca que a noção de jurisdição, na concepção moderna, não representa mais poder, mas somente função, atividade e garantia. Segundo a Autora, o principal indicador da jurisdição é, sobretudo, o da garantia do acesso à justiça, estatal ou não, e o seu objetivo, o de pacificar com justiça.

É nesse contexto que se afirmam os novos métodos adequados de resolução de conflitos, inseridos na terceira onda renovatória proposta na tese desenvolvida por Mauro Capelletti e Bryant Garth (1998, p. 12), acerca das soluções práticas para os problemas de acesso amplo à justiça. Segundo os Autores, a primeira solução restou alcançada com a assistência judiciária aos mais pobres; a segunda onda renovatória introduziu importantes reformas para proporcionar uma representação jurídica dos interesses difusos; a terceira, e mais recente solução, abarca as ondas anteriores, mas vai muito além, representando uma forma de atacar as barreiras ao acesso à justiça de maneira mais articulada e compreensiva. Capelletti e Garth propõem que a terceira onda centra a sua atenção no conjunto geral de instituições e mecanismos, pessoas e procedimentos utilizados para processar e mesmo prevenir as disputas nas sociedades modernas. Para eles, cada vez mais se reconhece, muito embora não se possa negligenciar as virtudes da representação judicial, que o movimento de acesso à justiça exige uma abordagem mais complacente da reforma, de maneira que a enorme demanda, latente por métodos que tornem os novos direitos mais efetivos, seja capaz de forçar uma nova reflexão sobre o atual modelo jurisdicional de suprimento dos conflitos (CAPELLETTI; GARTH, 1998, p. 25-26).

Nos Estados Unidos da América, a partir de 1976, o professor alemão Frank Sander, da Faculdade de Direito de Harvard, idealizou o conceito do chamado Tribunal Multiportas (multi-door 
courthouse), como uma instituição inovadora, que direciona os processos que chegam aos Tribunais para os meios mais adequados de solução de conflitos, economizando tempo e dinheiro para as instituições e os litigantes. Numa breve explicação, a ideia consiste em examinar a utilidade das diversas formas de resolução de conflitos, como a mediação, a arbitragem, a negociação e a medarb (combinação de mediação e arbitragem). Segundo o idealizador do modelo, observa-se cada modalidade diferente de processo para encontrar alguma taxonomia para aplicar aos conflitos, identificando que portas seriam adequadas a quais conflitos. Muito embora a proposta do Tribunal Multiportas seja uma ideia relativamente simples, a sua execução não é simples, porque decidir quais os casos devem ir para qual porta é uma tarefa bastante complexa (ALMEIDA; CRESPO, 2012, p. 32).

No Brasil, é possível defender que a arbitragem representou uma segunda porta de acesso à justiça, como uma alternativa à jurisdição institucional do Estado (primeira porta), notadamente com o advento da Lei oㅜ 9.307, de 23 de setembro de 1996. Caracterizada como um método típico para a solução litígios relativos aos direitos patrimoniais disponíveis, a arbitragem já estava prevista na Lei dos Juizados Especiais no 9.099, de 26 de setembro de 1995, preconizando, em seu art. 24, que não obtida a conciliação, poderiam as partes optar, de comum acordo, pelo juízo arbitral, independentemente de termo de compromisso, podendo decidir por equidade. Na mesma linha, a própria Constituição Federal de 1988, ao tratar das competências da Justiça do Trabalho, em seu art. $114, \S 2^{\circ}$, igualmente dispunha sobre a utilidade da negociação e da arbitragem para a solução de dissídios coletivos.

No fim de 2010, uma terceira porta acabou sendo descortinada, avançando-se mais intensamente no caminho da conciliação e da mediação, com a publicação da Resolução no 125 , de 29 de novembro de 2010, do Conselho Nacional de Justiça, que instituiu a Política Judiciária Nacional de tratamento dos conflitos de interesses, tendente a assegurar a todos o direito à solução dos conflitos por meios adequados à sua natureza e peculiaridade. Visando a boa qualidade dos serviços e à disseminação da cultura de pacificação social, a Política Judiciária do Conselho Nacional de Justiça passou a pregar a centralização das estruturas judiciárias, a adequada formação e treinamento de servidores, conciliadores e mediadores, bem como o acompanhamento estatístico específico dos litígios (art. $2^{\circ}$ ).

Em 2015, a partir de reformas introduzidas na Lei Arbitragem pela Lei ํㅜ 13.129, de 26 de maio de 2015, consolidaram-se importantes avanços doutrinários e jurisprudenciais a respeito do procedimento arbitral, como o reconhecimento expresso da admissibilidade do instituto para a solução de conflitos envolvendo a Administração Pública. No mesmo ano, a publicação do novo Código de Processo Civil, por meio da Lei oㅜ 13.105, de 16 de março de 2015, estabeleceu o estímulo às formas consensuais de solução de controvérsias (art. $3^{\circ}$, $\S 3^{\circ}$ ), disciplinando paralelamente a mediação familiar e a audiência preliminar de conciliação ou medição. Ainda em 2015, uma outra porta foi introduzida com o advento do Marco Legal da Mediação, instituído pela Lei n- 13.140 , de 26 de junho de 2015, dispondo a respeito da mediação entre os particulares como mecanismo de solução de controvérsias e sobre a autocomposição de conflitos no âmbito da Administração Pública. 
Atualmente, o ordenamento brasileiro vivencia um momento de afirmação do Tribunal Multiportas, instrumentalizando-se para oferecer aos jurisdicionados múltiplas alternativas de solução de conflitos, prestadas diretamente pelo Estado, ou, minimamente, não recusadas. Isso porque, sem dúvidas, cada espécie de conflito pressupõe um correspondente método mais adequado de resolução. A jurisdição estatal impositiva, de fato, é um dos clássicos e mais eficazes instrumentos de regulação e pacificação social, mas certamente não é capaz de suprir todas as potencialidades de divergências existentes na sociedade organizada. O Direito possui objetivos que pretende disciplinar, mas não consegue, inegavelmente, exaurir toda a extensão de relações intersubjetivas formadas no seio das sociedades, porquanto as escolhas político-ideológicas somente tutelam, circunstancialmente, aqueles bens jurídicos que são considerados mais relevantes. Muitas vezes, dessa forma, acaba sobrando para o Direito a solução de diversos conflitos não jurídicos e anteriormente não resolvidos, muitos deles alocados na esfera do permitido-permitido (ENTELMAN, 2005, p. 66).

No que se refere à arbitragem, notadamente, o Brasil possui uma relação história bastante antiga com o instituto, desde as suas primórdias legislações, como a Constituição do Império de 1824, as Ordenações do Reino e o Código Comercial de 1850 (CAHALI, 2015, p. 38). No entanto, apesar de toda a legislação então existente, até recentemente o próprio ordenamento jurídico desprestigiava o procedimento arbitral como um meio relevante de solução de conflitos, em especial pela exigência de homologação judicial das decisões arbitrais, situação abolida pela legislação vigente.

Por oportuno, convém salientar que a arbitragem não representa um método melhor de solução de conflitos, nem tampouco um instrumento pior que os demais mecanismos existentes. Trata-se, na verdade, tão somente de um caminho diferente, cujo procedimento individualiza-se por vocações e características próprias, a exemplo do custo-benefício, do caráter técnico e da qualidade das decisões, da possibilidade de indicação ou participação na escolha do árbitro ou da Câmara Arbitral, da previsibilidade das decisões, da flexibilidade do procedimento, da independência e da imparcialidade dos julgadores, da possibilidade de confidencialidade, da liberdade de escolher da lei aplicável e do local da arbitragem, entre outros.

Ao longo dos últimos anos, o Brasil ocupou em espaço destacado no cenário da arbitragem internacional. Atualmente, o país é o terceiro com mais partes envolvidas em processos arbitrais na Corte Internacional de Arbitragem, representando $30 \%$ do total de casos oriundos da América e do Caribe em 2016. Das 966 arbitragens registradas pela Corte Internacional, cerca de 123 referiam-se a empresas brasileiras, envolvendo valores da ordem de aproximadamente US $\$ 100$ milhões (ICC, 2017).

Em curto período de tempo, a arbitragem afirmou-se como método adequado de solução de conflitos no Brasil, rompendo preconceitos e cravando a sua marca na moderna hermenêutica do processo e da jurisdição. Sobre o tema, há farta doutrina e jurisprudência em construção, fomentadas por importantes eventos e debates institucionais, que, ademais, propõem e legitimam diversas soluções normativas, a exemplo da Primeira Jornada sobre a "Prevenção e Solução Extrajudicial de Litígios", realizada pelo Centro de Estudos Judiciários do Conselho da Justiça Federal (CBAr, 2016). 
Hoje, atingiu-se um entendimento, difundido com razoável clareza, de que a arbitragem não representa um método amigável de solução de conflitos, mas sim um procedimento adversarial e heterocompositivo. Todavia, com uma mesma percepção, se reconhece que a via arbitral é caminho cavalheiresco e colaborativo, cujos procedimentos poder ser melhor ajustados aos interesses dos litigantes. Superou-se, também, a noção do procedimento arbitral como alternativa à composição. Quem pretende um acordo não busca a arbitragem; quem procura a arbitragem não quer um acordo.

A arbitragem, paralelamente, notabilizou-se por ser um mecanismo de resolução de conflitos geralmente mais célere que a clássica jurisdição estatal, o que pode ser negado a depender da complexidade dos conflitos e das causas.

A arbitragem é um procedimento especializado, sendo importante lembrar que respostas muito simples e rápidas podem nem sempre representar o melhor resultado para os problemas complexos!!!!. Da mesma forma, a arbitragem tende a apresentar um custo mais elevado que o dos procedimentos judiciais, impondo-se avaliar o custo-benefício de cada caminho buscado para a resolução das lides. Não se pode olvidar, outrossim, que o processo judicial estatal é mais barato porque é fortemente subsidiado, mas não é um meio especializado de jurisdição. Já a arbitragem, sendo uma modalidade de jurisdição privada, possui um custo equivalente ao preço real do serviço prestado, muito embora os valores possam variar entre as diversas instituições arbitrais, algumas mais caras e outras menos onerosas. As grandes Câmaras de arbitragem certamente possuem um custo mais elevado, exatamente em razão da experiência e expertise, necessárias nos casos de alta complexidade. Somente com a massificação dos métodos adequados de resolução de conflito será possível obter um acesso mais barato às Câmaras Arbitrais, mas isso exigirá que os litigantes adquiram maior confiança no modelo e busquem a utilização de diferentes instituições e profissionais.

Outro aspecto a ser destacado reside no fato de que a arbitragem nem sempre representa uma opção mais adequada que a busca pelo Poder Judiciário. É cediço que a arbitragem é proibida em relação à discussão de determinados direitos (não patrimoniais e indisponíveis). Noutros casos, a arbitrabilidade é ainda bastante questionável, provocando certa incerteza jurídica para as partes a opção pelo juízo arbitral. Logo, o Poder Judiciário pode apresentar sim, em diversas situações, respostas melhores ao cidadão-jurisdicionado. No entanto, optando os cidadãos pela via adequada da arbitragem, a própria lei reconhece que deve ser preservada a autonomia da vontade das partes, notadamente em prestígio aos princípios da autonomia da cláusula e da competência-competência.

Outrossim, o processo arbitral pode ser mais célere, seja porque as instâncias arbitais são mais rápidas a decidir, seja porque as formalidades procesuais tendem a ser menos pesadas, seja ainda porque algumas jurisdições conferem ao Tribunal Arbitral o poder de dirigir o processo de forma livre, desde que os direitos essenciais e processuais das partes sejam respeitados. No caso da arbitragem em Portugal, ela se caracteriza pela autonomia do Tribunal Arbitral para conduzir o processo arbitral, pela oralidade e imediação na discussão da matéria de facto, bem como pela liberdade de apreciação dos factos e de determinação das diligências de produção da prova necessárias, de acordo com as regras de experiência e a livre convicção dos árbitros (Decreto-Lei n.ำ 10/2001, art.ำ 16.ํ). 
Derradeiramente, as Câmaras e demais instituições arbitrais possuem regras que Ihes são especificamente próprias, as quais devem ser observadas com rigor, a despeito da flexibilidade, sob pena de consequências patológicas, tanto em relação à forma quanto ao conteúdo das decisões. Em geral, os procedimentos arbitrais são típicos em cada umas das instituições, constituindo objeto de uma disciplina própria, com as suas normas ajustadas aos interesses materiais e processuais característicos de cada tipo de conflito. Nesse sentido, a legislação processual civil ordinária não é necessariamente aplicável à arbitragem, muito embora possa ser adotada, caso represente o interesse dos litigantes. $O$ rito do procedimento arbitral é escolhido pelas partes, conforme a conveniência e os interesses em jogo. Há, pois, uma imensa flexibilidade nessa eleição, afastando-se qualquer rigidez impositiva, de modo que a preferência pelos procedimentos implica em responsabilidades e uma certa dose de imprevisibilidade para os interessados. Por essa razão, justamente, o profissional capacitado e talentoso é fundamental para a condução do procedimento arbitral.

\section{A ARBITRAGEM NOS CONFLITOS ENVOLVENDO A ADMINISTRAÇÃO PÚBLICA}

Durante as duas últimas décadas ocorreram acirradas discussões a respeito da admissibilidade da arbitragem para a resolução de conflitos envolvendo o Poder Público, justamente pelo papel importante que a Administração exerce na economia, suscitando, não raras as vezes, significativos conflitos de interesses. Na realidade, a própria Administração Pública tratou de contribuir relevantemente para a formação de inúmeras das incertezas a respeito da arbitrabilidade nas contratações públicas, sobretudo levando a Juízo diversas controvérsias destinadas a afastar a incidência do juízo arbitral de seus litígios, mesmo que formalmente celebrada a cláusula da convenção arbitral. A grande questão que se coloca (e que sempre se colocou), portanto, é entender por que a Administração Pública não poderia valer-se da arbitragem para a solução de seus conflitos? O que difere as pessoas públicas das pessoas privadas nesses casos?

Inicialmente, imperioso destacar um aspecto estritamente ético desse debate, pois diversos questionamentos restaram suscitados pela própria Administração em relação à legalidade das convenções arbitrais livremente estipuladas em contratos celebrados pelas pessoas públicas, evidentemente na contramão da boa-fé e confiança exigida nas relações contratuais. Obviamente, não faz qualquer sentido que a Administração rejeite ou busque desfazer os ajustes de arbitragem que expressamente concordou em se submeter. Sobre a matéria, o Superior Tribunal de Justiça teve a oportunidade de manifestar-se, notadamente em relação aos contratos firmados pelas sociedades de economia mista exploradoras de atividade econômica de produção ou comercialização de bens ou

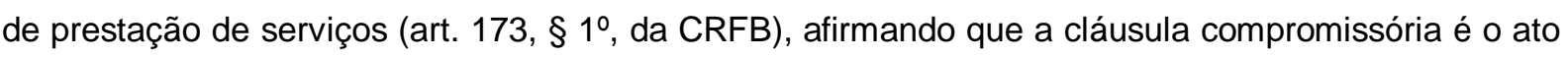
pelo do qual os contratantes formalizam o seu desejo de submeter à arbitragem eventuais divergências ou litígios, de modo que ficam vinculados à solução extrajudicial (REsp 612.439/RS).

Há algum tempo, nesse sentido, a jurisprudência pátria foi-se construindo em favor da arbitrabilidade dos litígios oriundos das contratações públicas. Em 1973, por ocasião do histórico julgamento do Caso Lage pelo Supremo Tribunal Federal, consubstanciado no Agravo de Instrumento 
№ 52.181, o Judiciário reconheceu a legalidade do juízo arbitral, mesmo nas causas contra a Fazenda Pública, porquanto o instituto sempre foi admitido e consagrado pelo Direito brasileiro. $\mathrm{Na}$ oportunidade, firmou-se o posicionamento a favor da legitimidade da cláusula de irrecorribilidade das sentenças arbitrais, porque não ofensivas às disposições normativas de índole constitucional.

Nesse caminho de afirmação da arbitragem pública, não foram poucas as situações em que o poder exorbitante inerente aos contratos administrativos serviu de motivação para a desconstituição de convenções de arbitragem, sobretudo a partir de alegações sustentadas em prerrogativas especiais da Administração, que a colocam em posição de supremacia em relação aos contratados. Tal assertiva, atualmente superada, como não poderia deixar de ocorrer, não resistiu ao argumento singelo de que a instituição arbitral não pressupõe a necessidade de equivalência de posições entre a Administração Pública e os particulares contratados. Nesse norte, o voto proferido pela Ministra Nancy Andrighi, ao apreciar o REsp 904.813/PR, sustentou que tanto a doutrina quanto a jurisprudência sinalizaram que não há óbice legal à estipulação da arbitragem pelo Poder Público, notadamente por sociedades de economia mista, admitindo-se como válidas as cláusulas compromissórias previstas nos editais convocatórios de licitação e contratos. Mais do que isso, mesmo o fato de não existir uma previsão expressa da arbitragem no edital de licitação ou no contrato celebrado, não invalida o compromisso arbitral firmado posteriormente.

Paralelamente, invocações recorrentes por parte da Administração Pública para afastar a admissibilidade da arbitragem recaíam sobre a parcela do seu poder discricionário. Tal alegação, igualmente impertinente, não se impõe porque inexiste obrigatoriedade quanto à celebração da convenção arbitral pelo Poder Público; ao contrário, a escolha pelo juízo arbitral reside na margem de

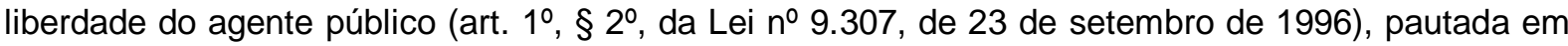
critérios de necessidade, conveniência e oportunidade, para, motivadamente, eleger o método adequado de solução de eventuais conflitos. Desse modo, manifestada a opção pelo juízo arbitral, deve-se prestigiar a previsibilidade, a confiança e a segurança do meio escolhido. Ademais, a discussão sobre a existência ou não de esfera de atuação discricionária, seja em procedimento arbitral ou processo judicial, constitui uma matéria de mérito, e não condição da ação ou pressuposto de admissibilidade da arbitragem.

Com o advento da Lei ํㅜ 13.129, de 26 de maio de 2015, uma grande parte da problemática sobre a arbitrabilidade das contratações públicas restou superada, em especial pela previsão específica do art. 1ํ, $\S 1^{\circ}$, dispondo que a Administração Pública, direta e indireta, poderá utilizar-se da arbitragem para dirimir os seus conflitos relativos a direitos patrimoniais disponíveis. A partir reforma normativa, ruíram também as tentativas de rejeitar o compromisso arbitral celebrado com fundamento ou invocação de nulidades em contratos administrativos, haja vista que o tema é especificamente abordado pela Lei de Arbitragem, estipulando que a cláusula compromissória é autônoma em relação ao contrato em que estiver inserta, de tal sorte que a nulidade deste não implica, necessariamente, o prejuízo à cláusula compromissória (art. 8º).

$\mathrm{Na}$ verdade, a inovação legal somente veio a reforçar a práxis dos procedimentos arbitrais envolvendo o Poder Público e oferecer uma maior segurança jurídica às relações contratuais, uma vez que a viabilidade desse método adequado de solução de conflitos há tempos vinha sendo 
defendida com robustez pela doutrina e jurisprudência, na esteira de previsões específicas contidas em farta legislação extravagante. É preciso, dessa forma, encerrar definitivamente o preconceito de que a arbitragem empreendida pela Administração Pública implica lançar mão de direitos. Ao contrário, não existe qualquer sacrifício, nem há tampouco renúncia de direito material, quando se escolhe a via do juízo arbitral, mas tão somente uma opção por um meio diferente de jurisdição.

Nesse contexto, a Lei № 9.472, de 16 de julho de 1997, que dispôs sobre a organização dos serviços de telecomunicações, a criação e o funcionamento de um órgão regulador, estabeleceu que as condições para a interconexão de redes deveriam ser objeto de livre negociação entre os interessados, mediante acordo, sob a pena de a Agência, por provocação de um deles, arbitrar as condições para a interconexão (art. 153, § $2^{\circ}$ ); nesse mesmo ano, a Lei do Petróleo no 9.478, de 06 de agosto de 1997, previu a necessidade de regras sobre a solução de controvérsias, relacionadas com o contrato de concessão de petróleo e gás natural, inclusive a conciliação e a arbitragem internacional (art. 43, X); do mesma forma, a Lei no 12.351, de 22 de dezembro de 2010, estabeleceu a essencialidade das cláusulas sobre a ar-bitragem nos contratos de partilha de produção de petróleo, de gás natural e de outros hidrocarbonetos fluidos (art. 29, XVIII); já a Lei de Concessões no 8.987, de 13 de fevereiro de 2005, com as suas posteriores alterações, estipulou que o contrato poderia prever o emprego de mecanismos privados para resolução de disputas decorrentes ou relacionadas ao contrato, inclusive a arbitragem (art. 23-A); ainda, a Lei das Parcerias PúblicoPrivadas $\mathrm{n}^{\circ}$ 11.079, de 30 de dezembro de 2004, igualmente dispôs sobre a previsão do emprego dos mecanismos privados de resolução de disputas, inclusive a arbitragem, nos conflitos relacionados ao contrato (art. 11, III); paralelamente, a Lei ㄲo 12.462, de 4 de agosto de 2011, também estabeleceu a possibilidade de opção pela arbitragem nas licitações e nos contratos submetidos ao Regime Diferenciado de Contratações Públicas; mais recentemente, a Lei № 13.448, de 5 de junho de 2017, tratou do compromisso arbitral entre as partes, com previsão de submissão, à arbitragem ou a outro mecanismo privado de resolução de conflitos admitido na legislação aplicável, na prorrogação e

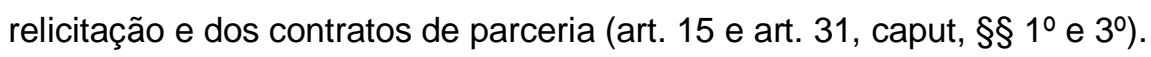

Em realidade, toda a celeuma atinente à admissibilidade da arbitragem para a resolução de conflitos envolvendo o Poder Público, antes de tudo, é uma questão de arbitrabilidade objetiva. A respeito do assunto, Francisco José Cahali (2015, p. 133) explica que a arbitrabilidade é uma condição essencial para que um determinado conflito seja submetido à arbitragem, representando o filtro dos litígios que poderão ser encaminhados ao juízo arbitral. A capacidade das partes para firmarem a convenção é conditio sine qua non para a utilização da arbitragem, correspondendo a arbitrabilidade subjetiva; de outro lado, para o atendimento da arbitrabilidade objetiva, exige-se que o objeto do litígio diga respeito especificamente ao tipo de direito delimitado na legislação (CAHALI, 2015, p. 133-134).

Toda vez em que se discute sobre a admissibilidade da arbitragem em relação aos litígios resultantes de contratações administrativas, a problemática frequentemente repousa sobre as dificuldades relacionadas à arbitrabilidade objetiva, porquanto a Administração Pública, estando representada por pessoas jurídicas de Direito Público (personificadas, portanto), cujos titulares são sujeitos legitimamente capazes e competentes, dotados de direitos e deveres, não há maiores 
dificuldades para se reconhecer a capacidade para a manifestação de interesses (arbitrabilidade subjetiva).

Para a aferição da arbitrabilidade objetiva, todavia, deve-se partir da leitura do art. 1을 $\S 1^{1 \stackrel{0}{ }}$, da Lei de Arbitragem no 9.307, de 23 de setembro de 1996, ao dispor que "a administração pública direta e indireta poderá utilizar-se da arbitragem para dirimir conflitos relativos a direitos patrimoniais disponíveis". Assim sendo, está positivado que a arbitragem relacionada às contratações públicas é admissível para a resolução de conflitos envolvendo "direitos patrimoniais disponíveis". Mas o que seriam, no entanto, esses chamados direitos patrimoniais e disponíveis?

Num primeiro aspecto, a chamada patrimonialidade que caracteriza a arbitragem refere-se aos interesses cujo objeto reveste-se de conteúdo econômico ou de expressão monetária. O Código Civil brasileiro preconiza que é admitido o compromisso, judicial ou extrajudicial, para resolver os litígios entre pessoas que podem contratar (art. 851), sendo vedado o compromisso para a solução de questões de estado, de direito pessoal de família e outras que não tenham caráter estritamente patrimonial (art. 852). Segundo Francisco José Cahali (2015, p. 135), os direitos não patrimoniais estão excluídos de plano do juízo arbitral, a exemplo dos direitos de personalidade e do estado da pessoa, sem prejuízo de eventuais impactos patrimoniais desses direitos, estes sim sujeitos à arbitragem.

Superada a questão da patrimonialidade, a arbitrabilidade objetiva enfrenta maior controvérsia diante do debate que se fundamenta no postulado da indisponibilidade do interesse público. De acordo com José dos Santos Carvalho Filho (2012, p. 34), o princípio da indisponibilidade parte da premissa de que todos os cuidados exigidos para os bens e interesses públicos trazem benefícios para a própria coletividade. Segundo o Autor, os bens e os interesses não pertencem à Administração Pública nem a seus agentes, cabendo-Ihes apenas geri-los, conservá-los e por eles velar em prol da coletividade, esta sim a verdadeira titular dos direitos e interesses públicos. Em suma, pode-se dizer que a indisponibilidade é corolário da República (res publica).

Hely Lopes Meirelles (2011, p. 260), não obstante, explica que a indisponibilidade possui vertentes distintas, decorrentes do interesse público primário e secundário. Para o Autor, na primeira hipótese, o objetivo final são as ações próprias do Estado, como o atendimento das necessidades essenciais dos cidadãos; já no segunda caso, o objetivo é instrumentalizar o interesse primário, utilizando-se a Administração dos meios úteis e necessários à efetivação das ações próprias de Estado, cuja satisfação geralmente se concretiza sob a égide do Direito Privado e se resolve em relações patrimoniais. Desse modo, não existe qualquer prejuízo em conciliar a indisponibilidade do interesse público com as matérias que podem ser objeto da arbitragem, permitindo assim uma melhor perspectiva a respeito dos direitos patrimoniais disponíveis (MEIRELLES, 2011, p. 261). Seguindo essa corrente, o Ministro Luiz Fux, no julgamento do AgRg em MS 11.308-DF, assentou que a escorreita exegese da dicção legal impõe uma distinção jus-filosófica entre o chamado interesse público primário e o interesse da Administração, cognominado de interesse público secundário, sendo reconhecido pela doutrina e pela jurisprudência que indisponível é o interesse público, e não o interesse da Administração. Em verdade, como aduz o Ministro, não há que se negar a aplicabilidade 
do juízo arbitral em litígios administrativos quando presentes os direitos patrimoniais do Estado, mas ao contrário, até mesmo incentivá-la.

Em sentido diametralmente oposto, importante registrar, Celso Antônio Bandeira de Mello (2012, p. 804) encara a arbitragem nos litígios públicos como novidade lamentável e grosseiramente inconstitucional. Como afirma o Autor, o grotesco entendimento representa disparate de um tão desabrido teor que só poderia ser concebido no dia em que se reputasse normal que os motoristas multassem os guardas de trânsito. A tese que predomina entre os administrativistas, contudo, revela que a Administração pode dispor de alguns interesses (renunciáveis), justamente objetivando alcançar a finalidade pública, esta sim irrenunciável. Em outros termos, é preciso reconhecer que existem duas concepções diferentes para a (in)disponibilidade. Na primeira delas, encontra-se associada à impossibilidade de renúncia dos direitos, o que constitui uma regra geral aplicável à Administração. A indisponibilidade, nesses casos, refere-se ao próprio direito material em evidência. $\mathrm{Na}$ segunda acepção, a indisponibilidade traduz a impossibilidade de reconhecer a procedência de posições alheias aos interesses da Administração Pública, o que não representa uma regra absoluta aplicável ao Poder Público. Nessa hipótese, a indisponibilidade afina-se com a pretensão da tutela jurisdicional, ou seja, o direito de submeter (ou não) a causa ao Poder Judiciário.

A correta exegese do art. 1ำ, $\S 1^{\circ}$, da Lei de Arbitragem, portanto, aponta para a aferição da necessidade ou não do controle jurisdicional necessário de conflitos envolvendo a Administração Pública, a exemplo do que ocorre com a aplicação da lei penal, com os direitos de capacidade, com as questões falimentares etc. Dessa maneira, a disponibilidade dos direitos patrimoniais da Administração Pública reside na ausência de uma intervenção obrigatória pelo Poder Judiciário na resolução dos litígios. Conforme pondera Marçal Justen Filho (2011, p. 768), o óbice à arbitragem nesses casos encerra uma contradição invencível, que conduziria a excluir a própria existência dos contratos administrativos. Toda a convenção arbitral é apenas uma simples manifestação de cunho contratual, de modo que todas as questões que comportam disciplina pela via contratual, igualmente admitem a instituição de arbitragem. Conforme o Autor, a disponibilidade para impor a arbitragem é aquela mesma para criar os direitos e as obrigações pela via consensual (JUSTEN FILHO, 2011, p. 768). São arbitráveis, dessa forma, questões relacionadas ao reequilíbrio da equação econômicofinanceira de contratos administrativos, ao cumprimento das obrigações contratuais pública, às consequências da extinção de contratos administrativos etc.

Em suma, para fins de arbitrabilidade objetiva, a relevância da disponibilidade encontra-se apenas nos interesses públicos secundários, porquanto o objeto de qualquer convenção de arbitragem é sempre e apenas o modo de solução de algum conflito. Eduardo Talamini acrescenta, ademais, que não se ignora o fato de a Administração Pública vir a ser derrotada na arbitragem, o que representa uma das consequências possíveis em qualquer moldura jurisdicional. Para o Autor, mesmo que a Administração Pública acabe derrotada, ainda assim não haverá qualquer renúncia ou ato de disposição, significando apenas que ela não possuía razão quanto ao que pretendia. Noutros termos, a derrota no procedimento arbitral não representa afronta ou menoscabo ao interesse público (TALAMINI, 2005, p. 345). 
Seguindo exatamente essa linha, a própria legislação prevê expressamente que a arbitragem envolvendo a Administração Pública será sempre de direito, vedado o juízo de equidade. Ou seja, as partes podem optar, dentro das regras do Direito, qual melhor lhes convém para o deslinde da controvérsia. A razão é bastante lógica e apenas corrobora o entendimento predominante acerca do instituto, que reconhece a indisponibilidade quanto ao direito material, por meio de juízos meramente discricionários.

Ao final, é preciso reconhecer que a própria Lei de Arbitragem reafirmou garantias processuais específicas, prevendo, em especial, que o procedimento arbitral envolvendo a Administração Pública deverá respeitar o princípio da publicidade. Não se olvida, ademais, malgrado a arbitragem possua certa informalidade, que a chamada constitucionalização do Direito tem provocado certo influxo sobre a teria moderna da arbitragem, sendo certo que, para além das normas convencionais, incidem sobre o procedimento também os princípios jurídicos, especialmente os processuais, diversos deles de status constitucional (FICHTNER, MANNHEIMER, MONTEIRO, 2014, p. 27-33). Nessa linha, a lei é textual ao preconizar que serão respeitados no procedimento arbitral, sempre, o contraditório, a igualdade das partes, a imparcialidade do árbitro e o seu livre convencimento (art. 12, § $2^{\circ}$ ).

\section{AS PERSPECTIVAS DA ARBITRAGEM TRIBUTÁRIA NO DIREITO BRASILEIRO}

A Constituição Federal de 1988 inaugurou uma Nova Era de Direitos no Brasil, abrigando a proteção de valores fundamentais e universalmente reconhecidos. Em matéria de tributação, a Magna Carta mostrou-se especialmente analítica e minuciosa, a ponto de merecer inúmeras críticas desde a sua promulgação. Como observa Ives Gandra da Silva Martins (2008, p. 11), trata-se de uma evidente carta de direitos dos contribuintes contra a excessiva carga tributária da Federação tripartida que é o Brasil, único país do mundo a outorgar competência constitucional aos municípios.

Apesar dos avanços empreendidos pela CRFB, o Sistema Tributário Nacional não resistiu a severas reprovações, tamanha é a sua complexidade e reconhecida ineficiência, atualmente refletida em altíssimos custos, elevada carga e incomensurável insegurança jurídica. Ives Gandra Martins, logo depois da publicação do texto constitucional, asseverou que, do ponto de vista econômico, o sistema tributário era inflacionário; do ponto de vista jurídico, imperfeito; e do ponto de vista político, tirânico. Segundo o Autor, o sistema tributário poderia mesmo representar o necrológico da Democracia, na medida em que, aumentando consideravelmente as obrigações dos contribuintes, desestimulava a poupança, o trabalho e o investimento (ZAVARIZI, 2006, p. 152).

Em que pese a inegável necessidade de ajustes no sistema, a voracidade do Fisco impede os avanços legislativos e a implementação de medidas concretas no sentido de promover a tão esperada reforma tributária, inclusive nos aspectos atinentes ao processo de cobrança fiscal. Ainda assim, mesmo sem maior qualidade, a quantidade e a velocidade das alterações normativas é absolutamente espantosa. A legislação tributária acostumou-se a conviver com inúmeras modificações de atropelo, impossibilitando até mesmo o mais zeloso estudioso da tributação a acompanhar a evolução das normas. Desde o ano de 1988, com a promulgação da Constituição 
Federal, cerca de 350 mil normas tributárias foram editadas, segundo os números divulgados pelo Instituto Brasileiro de Planejamento Tributário. Foram editadas, durante esse curto período, 31 normas tributárias por dia, em média, ou 1,29 norma tributária por hora (IBPT, 2015).

A escalada da tributação é crescente e a carga total da arrecadação atingiu, no ano de 2015, aproximadamente $32,66 \%$ do Produto Interno Bruto. Levantamentos disponibilizados pelo Ministério do Planejamento apontam que o volume da arrecadação permaneceu relativamente estável ao longo da última década, após o significativo incremento durante o período pós-estabilidade econômica, a partir de 1994 (MPOG, 2015). É curioso notar, contudo, que esse volume de arrecadação representava um valor muito menos expressivo nos anos que antecederam a promulgação da Constituição, girando em torno de $20 \%$ do Produto Interno Bruto, o que denota uma evolução da carga tributária em quase 70\%, num período de menos de trinta anos. O impostômetro da Associação Comercial do Estado de São Paulo, somente no ano de 2016, calculou uma arrecadação de aproximadamente 2 trilhões, 4 bilhões e 500 milhões (ACSP, 2016).

Os cidadãos brasileiros precisam trabalhar cerca de 153 dias por ano, ou seja, cinco meses e um dia, apenas para suportar as exigências tributárias, o que consome $41,80 \%$ dos seus rendimentos, aproximadamente (IBPT, 2016). Atualmente, trabalha-se no Brasil o dobro do que se trabalhava durante a década de 70 para fazer frente à carga tributária. A título de exemplo, o contribuinte brasileiro trabalha uma quantidade de dias equivalente à de um contribuinte norueguês para arcar com os seus impostos, sendo muito evidente, porém, a disparidade de contrapartidas oferecidas por cada um dos países. Os dados estarrecedores só confirmam as notórias dificuldades associadas à incerteza jurídico-tributária, à falta de previsibilidade e aos problemas ligados ao planejamento fiscal eficiente.

Nesse cenário, a massificação dos mecanismos de substituição tributária e dos procedimentos de lançamento por homologação (auto lançamento) evidencia uma grave violência perpetrada contra os contribuintes, na medida em que o Fisco entrega aos próprios sujeitos passivos da obrigação tributária a tarefa árdua e complicadíssima de compreender adequadamente e aplicar uma legislação brutalmente complexa e muitas vezes ininteligível. Em relação aos sujeitos passivos restam exigidas atividades que, muitas vezes, nem mesmo os agentes do Fisco convergem quanto à interpretação, o que naturalmente acaba onerando a iniciativa privada e refletindo em altos custos que são repassados para toda a sociedade, diante de elevadas despesas agregadas à tributação, como a contratação de profissionais, sistemas e consultorias. Isso sem falar nas severas sanções previstas pela legislação nas hipóteses de eventuais falhas cometidas pelos contribuintes durante o intrincado percurso de constituição do crédito tributário. Aparentemente, o sistema tributário brasileiro sofre de uma grave crise de esquizofrenia.

$\mathrm{Na}$ outra ponta, a Lei de Execuções Fiscais tem-se demonstrado absolutamente desatualizada e ineficiente. Apenas uma parcela pouco significativa dos passivos tributários objeto de procedimentos judiciais de cobrança conseguem ser recuperadas. O Brasil não caminha no mesmo sentido das experiências tributárias mundiais, em termos de efetivação de ajustes, matérias e formais, mantendo uma grande parcela de sua população à margem de medidas efetivas direcionadas à conscientização, com poucas ações políticas voltadas ao esclarecimento, à educação, cultura e ética 
fiscal. Tudo isso potencializa, consequentemente, a avidez da Fazenda Pública por um auferimento cada vez maior de receitas, culminando muitas vezes em violações graves aos direitos dos contribuintes. Inegavelmente, há uma necessidade inadiável de ajustes no modelo tributário.

O sistema tributário nacional, complexo e deficitário, acaba estimulando e agravando também o problema da sonegação fiscal no Brasil, que, no final das contas, não se sabe se é mesmo a causa ou consequência da carga tributária elevada. $O$ desfalque na arrecadação, que impacta severamente na insuficiência de receitas públicas, é ainda potencializado pela cultura nababesca da Administração Pública, caríssima e perdulária, que evidencia ainda grandes resquícios do modelo patrimonialista que vigorou desde o Período Colonial. Segundo o sonegômetro do Sindicato Nacional dos Procuradores da Fazenda Nacional, somente nos primeiros 15 dias do ano de 2017, o Brasil perdeu aproximadamente 23 bilhões e 200 milhões com a sonegação de impostos (SINPROFAZ, 2017), cujos reflexos vêm sendo percebidos com o aumento devastador da Dívida Pública, capaz de entregar um legado nefasto para as futuras gerações de cidadãos brasileiros.

Mesmo diante um cenário tão conturbado, em que os instrumentos contenciosos destinados à exigência de tributos demonstram-se flagrantemente infrutíferos e ineficazes, olvidam-se as experiências bem-sucedidas em países europeus, notadamente em Portugal, com iniciativas exitosas no campo da arbitragem tributária, a exemplo do Decreto-Lei $n^{\circ}=10$, de 2011 , que disciplina a arbitragem como um meio alternativo de resolução jurisdicional de conflitos em matéria fiscal.

Atualmente, encontra-se em tramitação no Congresso Nacional o Projeto de Lei no 5.082, de 2009, que institui a Lei Geral de Transação Tributária, dispondo sobre transação tributária, atualmente submetido à Comissão Especial para a apreciação da matéria. Em seu texto, a proposta contempla a regulamentação do art. 156, inciso III, e do art. 171 do Código Tributário Nacional, estabelecendo as condições e os procedimentos que a União Federal, por intermédio da Procuradoria-Geral da Fazenda Nacional e da Secretaria da Receita Federal do Brasil, e os sujeitos passivos de obrigação tributária, deverão observar para a realização de transação, importando composição de conflitos ou terminação de litígio, para extinção do crédito tributário. Em linhas gerais, a grande virtude da proposição legislativa é reinaugurar a discussão sobre a regulamentação da transação, introduzida com o advento da Lei ํㅜ 5.172, de 25 de outubro de 1966. De acordo com o Projeto, já em seu art. 1ำ, parágrafo único, consta que a Fazenda Nacional, em qualquer modalidade de transação, em juízo de conveniência e oportunidade, obedecidos os requisitos legais, poderá celebrar transação, sempre que motivadamente entender que atende ao interesse público. Em sintética análise, porém, a proposta caminha unicamente no sentido de oferecer um reconhecimento maior às soluções tipicamente privadas para os conflitos tributários, sobretudo porque a transação não pode implicar a negociação do montante do tributo devido (art. $7^{\circ}$ ).

Tratar da arbitragem em temas tributários significa, em grande parte, reenfrentar algumas das problemáticas já debatidos (e algumas superadas) pela teoria administrativista brasileira. Nesse sentido, a admissibilidade da arbitragem tributária supõe reconhecer que a disponibilidade dos tributos repousa também sobre a ausência de um controle obrigatório dos litígios fiscais pelo Poder Judiciário. Nesse sentido, justamente, João Ricardo Catarino (2012, p. 16) rechaça peremptoriamente o óbice da indisponibilidade como um entrave para a implementação da arbitragem no Direito 
Tributário, porquanto, mesmo que houvesse na arbitragem a dispensa ou a renúncia ao imposto tão frequentemente citada por parte da doutrina, a indisponibilidade do interesse público deve ser analisada com temperamentos (CATARINO, ROSSINI, 2016). Segundo o Autor, a doutrina brasileira difere o interesse público primário do secundário, sendo que o primeiro se refere à promoção e à concretização de valores eleitos pela sociedade como um todo, enquanto os secundários são aqueles relacionados aos bens patrimoniais do Estado ou de suas entidades. Portanto, tratando-se os interesses estatais secundários, como bens e direitos eminentemente patrimoniais, a Administração Pública estaria autorizada a submeter-se ao juízo arbitral, por um motivo bastante singelo: os bens e direitos em referência existem única e exclusivamente para que o administrador público deles disponha para concretização de algum interesse primário.

Marco Aurélio Greco, por sua vez, formulando uma concepção contemporânea da atividade tributária, sustenta que o Poder Público se encontra investido numa função de tributar ao invés de um poder de fazê-lo. Como consequências práticas, destaca que a tributação, em especial, deve estar em sintonia com os objetivos constitucionais e ser compatível com a realidade à qual se aplica. Em paralelo, o Autor observa que o interesse arrecadatório e os poderes da fiscalização constituem interesses secundários, que dependem do interesse primário consistente na busca do atingimento dos objetivos constitucionais, de maneira que a exigência tributária que conflite com os desígnios constitucionalizados é tão inconstitucional como uma cobrança sem lei específica ou retroativa. Afirma o Autor, ainda, que a instituição, a permanência da cobrança do tributo, bem como a aplicação dos recursos devem estar em sintonia com as políticas públicas que justificam a sua criação; ou seja, o debate tributário supõe necessariamente a inserção da exigência pecuniária no âmbito dos instrumentos para o atendimento de certa política pública. Dessa maneira, sempre que a disposição contratual, inclusive a convenção de arbitragem, for realizada pelo administrador público em respeito ao cumprimento de suas funções, os atos praticados serão plenamente válidos (GRECO, 2012, p. 283).

Em Portugal, a arbitragem tributária é uma realidade que rompeu preconceitos. Francisco Nicolau Domingos (2016, p. 433-434) explica que o recurso à arbitragem foi tradicionalmente vedado em Direito Público, ao argumento de que a Administração tem encomendada a defesa do interesse público. Desse modo, o Fisco poderia utilizar o poder de império e atuar com fundamento no princípio da legalidade, razão pela qual somente os Tribunais teriam as condições de proceder o controle da atividade administrativa. Colocado de outro modo, o contencioso de legalidade de decisões administrativas estaria subtraído da arbitragem. Como esclarece o Autor, todavia, contribuíram para a superação dessa cultura, sobretudo, a massificação das relações administrativas, a ineficácia dos Tribunais para a solução de litígios fiscais, além do novo paradigma quanto ao modo de exercício dos poderes da Administração. Em síntese, conforme o modelo português, a arbitragem justificou-se pela celeridade, economia processual, especialização e experiência dos membros dos tribunais arbitrais (DOMINGOS, 2016, p. 436-438; CATARINO, FILLIPO, 2011 p. 613-645).

Em breve consideração, é possível afirmar que o Regime Jurídico da Arbitragem Tributária, introduzido no ordenamento jurídico português, é exclusivamente uma espécie de controle de legalidade, não sendo admissível a fiscalização ou a sindicância de mérito, conveniência ou 
oportunidade de decisões tributárias concretas. Malgrado o princípio da indisponibilidade do crédito tributário não esteja expressamente previsto na Constituição de Portugal, como também ocorre no Brasil, é corolário dos postulados da igualdade e da legalidade. Não obstante, face à globalidade do ordenamento jurídico lusitano, assim como aqui, não há obstáculo para que sejam emitidos juízos sobre a existência e a legalidade do crédito tributário por parte de órgãos diferentes dos Tribunais estatais (SOUSA, 2013, p. 98). Desse modo, se é certo que a Administração não está violando o princípio da indisponibilidade quando ela própria reconhece razão aos argumentos do contribuinte e elimina juridicamente um crédito tributário, é igualmente verdadeiro que os Tribunais Arbitrais não ferem a ordem jurídica quando realizam o controle de legalidade do litígio fiscal.

A arbitragem é, portanto, um procedimento heterocompositivo formal, previsto e disciplinado em legislação própria, que exige o cumprimento de requisitos formais. Não se trata de uma aposta, nem tampouco de uma aventura. Por meio da arbitragem tributária, o Estado não está a dispor do crédito tributário, mas a encarregar os próprios cidadãos da solução dos conflitos, munidos de idêntica responsabilidade para produzir uma decisão final, de acordo com os cânones do sistema tributário, nos mesmos moldes que qualquer juiz ou tribunal estatal (DOMINGOS, 2016, p. 386).

Parece evidente, desse modo, a partir dos aportes constitucionais, e com suporte na experiência comparada, que o ordenamento brasileiro possui um terreno fértil para progredir na implementação de sistemas alternativos (ou adequados) de solução de conflitos fiscais, precisando somente superar alguns dogmas não mais condizentes com a atual conjuntura institucional. João Ricardo Catarino (2012, p. 01-2) assinala que a possibilidade de introduzir no Direito Tributário novos métodos de dirimir conflitos fiscais que se situem para além dos mecanismos normais, públicos, nuns casos administrativos, noutros judiciais, esbarra num conjunto de ideias pré-concebidas e que dificultam a análise do tema, mas também o tornam aliciante. Para ० Autor, existem na exegese própria do Direito Tributário algumas concepções estruturantes e princípios que colocam o Estado numa posição de supremacia na relação tributária, sendo que ainda se invoca a indisponibilidade do crédito tributário para obstar à possibilidade de acordo entre as partes litigantes como uma forma de alcançar a composição justa dos direitos e deveres tributários (CATARINO, FILLIPO, 2011, p. 613645).

É importante observar, ademais, que o atual colapso das estruturas jurisdicionais brasileiras, ensejador de graves mazelas para os cidadãos-jurisdicionados, sobretudo o alto custo social e a morosidade do serviço, muito embora seja potencializado pelas demandas tributárias massificadas, possui reflexos muito mais amplos, abrangentes e perniciosos, não exclusivamente restritos ao subsistema tributário. Afirmar que o passivo tributário representa aproximadamente $1 / 3$ do total de demandas judicializadas não significa reconhecer somente um problema de jurisdição inadequada para os litígios fiscais, implicando, muito além disso, um grave prejuízo ao amplo acesso à jurisdição, pois o volume exagerado das execuções fiscais reverbera direta e gravemente sobre toda a estrutura de Administração da Justiça. O manifesto atraso em oferecer a prestação jurisdicional, imotivado e desarrazoado, traduz-se numa inegável quebra de confiança e perda da legitimidade do Poder Público para atuar com exclusividade na promoção da justiça, o que levou o ex-Ministro da Fazenda, 
Pedro Malan, a cunhar famosa a frase "no Brasil, até o passado é imprevisível" (THE ECONOMIST, 2014).

É necessário reconhecer que a realidade tributária brasileira não é insuscetível de transformações, sendo razoável acreditar que os novos desafios oriundos da globalização, desintermediação, desmaterialização e deslocalização dos fatos tributáveis possam contribuir para mudanças mais profundas (CATARINO, 2012, p. 01-2). No atual paradigma, o Estado e perde a sua centralidade na relação jurídico-tributária, passando os cidadãos-contribuintes a ocupar esse espaço, na qualidade de detentores verdadeiros do poder legítimo. Com isso, a sacralidade do Estado no plano tributário acaba sendo desmistificada, fomentando uma forte tendência de desjudicialização, impulsionada pela crise dos sistemas públicos justiça.

\section{CONSIDERAÇÕES FINAIS}

A necessidade de avanços na implementação dos meios de solução adequada de conflitos é praticamente uma unanimidade no Brasil. Paralelamente, é fato que os cidadãos brasileiros sofrem com a indolência e com o medo da efetivação de mudanças contundentes. A cultura do litígio (ou da sentença), fortemente arraigada na sociedade brasileira, impede a efetivação dos direitos e dos demais desígnios republicanos, solenemente enunciados pela Carta de 1988, retardando discussões que já não suportam mais esperar.

O sistema jurisdicional estatal é falho e prejudica quem menos pode esperar pelas soluções institucionais, inexistindo verdadeiro interesse para que muitos dos atores sociais realmente busquem uma atualização estrutural do modelo. A jurisdição estatal, subsidiada e morosa, é, a um só tempo, muito útil e inútil.

A legislação processual brasileira sofreu importantes avanços nos últimos tempos, logrando êxito em difundir procedimentos que oferecem maior suporte para a efetivação de uma cultura consensual. No âmbito público, igualmente, o reconhecimento pela própria justiça estatal da admissibilidade dos meios adequados para a solução de conflitos envolvendo a Administração Pública representou um importante avanço, encontrando, nos dias de hoje, pouca resistência por parte dos litigantes interessados.

Em relação à arbitragem tributária, a razoáveis expectativas para o progresso de concepções legais, doutrinárias e jurisprudenciais, notadamente a partir de experiência do direito comparado, que demonstram a perfeita admissibilidade do meio heterocompositivo para a solução de litígios fiscais. Grande parte dos problemas relacionados à arbitrabilidade dos conflitos tributários já foram tratados pela teoria administrativista, remanescendo superar, ainda, alguns aspectos pontuais relacionados à legislação específica.

\section{REFERÊNCIAS}

ALMEIDA, Rafael Alves de; ALMEIDA, Tania; CRESPO, Mariana Hernandez (ORG.). Tribunal Multiportas: investindo no capital social para maximizar o sistema de solução de conflitos no Brasil. Rio de Janeiro: Editora FGV, 2012. 
ASSOCIAÇÃO COMERCIAL DE SÃO PAULO (ACSP). Impostômetro, 2016. Disponível em: https://impostometro.com.br/. Acesso em: 13 de janeiro de 2017.

BANDEIRA DE MELLO, Celso Antônio. Curso de Direito Administrativo. 29. ed. rev. e atual. São Paulo: Malheiros, 2012.

BRASIL. Constituição (1988). Constituição da República Federativa do Brasil de 1988. Diário Oficial da União, Congresso Nacional, Brasília, DF, 191-A de 05/10/1988, p.1. Disponível em: http://www.planalto.gov.br/ccivil_03/constituicao/constituicaocompilado. htm. Acesso em: 10 de julho de 2017.

BRASIL. Lei no 8.987, de 13 de fevereiro de 1995. Dispõe sobre o regime de concessão e permissão da prestação de serviços públicos previsto no art. 175 da Constituição Federal, e dá outras providências. Diário Oficial da União, Atos do Poder Legislativo, Brasília, DF, de 14/02/1995, p. 1917. Disponível em: http://www.planalto.gov.br/ccivil_03/leis/L8987cons.htm. Acesso em: 10 de julho de 2017.

BRASIL. Lei no 9.099, de 26 de setembro de 1995. Dispõe sobre os Juizados Especiais Cíveis e Criminais e dá outras providências. Diário Oficial da União, Atos do Poder Legislativo, Brasília, DF, de 27/09/1995, p. 15033. Disponível em: http://www.planalto.gov.br/ccivil_03/leis/L9099.htm. Acesso em: 10 de julho de 2017.

BRASIL. Lei no 9.472, de 16 de julho de 1997. Dispõe sobre a organização dos serviços de telecomunicações, a criação e funcionamento de um órgão regulador e outros aspectos institucionais, nos termos da emenda Constitucional № 8, de 1995. Diário Oficial da União, Atos do Poder Legislativo, Brasília, DF, de 17/07/1997, p. 15081. Disponível em: http://www.planalto.gov.br/ccivil_03/leis/L9472.htm. Acesso em: 10 de julho de 2017.

BRASIL. Lei no 9.478, de 06 de agosto de 1997. Dispõe sobre a Política Nacional, as atividades relativas ao monopólio do petróleo, institui o Conselho Nacional de Política Energética e a Agência Nacional do Petróleo (ANP) e dá outras providências. Diário Oficial da União, Atos do Poder Legislativo, Brasília, DF, de 07/08/1997, p. 16925. Disponível em: http://www.planalto.gov.br/ccivil_03/leis/L9478.htm. Acesso em: 10 de julho de 2017.

BRASIL. Lei no 11.079, de 30 de dezembro de 2004. Institui normas gerais para licitação e contratação de parceria público-privada no âmbito da Administração Pública. Diário Oficial da União, Atos do Poder Legislativo, Brasília, DF, de 31/12/2004, p. 6. Disponível em: http://www.planalto.gov.br/ccivil_03/_ato2004-2006/2004/lei//11079.htm. Acesso em: 10 de julho de 2017.

BRASIL. Lei no 12.351, de 22 de dezembro de 2010. Dispõe sobre a exploração e a produção de petróleo, de gás natural e de outros hidrocarbonetos fluidos, sob o regime de partilha de produção, em áreas do pré-sal e em áreas estratégicas; cria o Fundo Social - FS e dispõe sobre sua estrutura e fontes de recursos; altera dispositivos da Lei ํo 9.478, de 6 de agosto de 1997; e dá outras providências. Diário Oficial da União, Atos do Poder Legislativo, Brasília, DF, de 23/12/2010, p. 1. Disponível em: http://www.planalto.gov.br/ccivil_03/_ato2007-2010/2010/lei/L12351.htm. Acesso em: 10 de julho de 2017. 
BRASIL. Lei no 12.462, de 4 de agosto de 2011. Institui o regime diferenciado de contratações públicas - RDC; altera a Lei oㅜ 10.683, de 28 de maio de 2003, que dispõe sobre a organização da Presidência da República e dos ministérios, a legislação da Agência Nacional de Aviação Civil (ANAC) e a legislação da Empresa Brasileira de Infraestrutura Aeroportuária (INFRAERO); cria a secretaria de aviação civil, cargos de ministro de estado, cargos em comissão e cargos de controlador de tráfego aéreo; autoriza a contratação de controladores de tráfego aéreo temporários; altera as Leis nos 11.182, de 27 de setembro de 2005, 5.862, de 12 de dezembro de 1972, 8.399, de 7 de janeiro de 1992, 11.526, de 4 de outubro de 2007, 11.458, de 19 de março de 2007, e 12.350, de 20 de dezembro de 2010, e a Medida Provisória no 2.185-35, de 24 de agosto de 2001; e revoga dispositivos da Lei o 9.649, de 27 de maio de 1998.. Diário Oficial da União, Atos do Poder Legislativo, Brasília, DF, de 05/08/2011, p. 1 (edição extra). Disponível em: http://www.planalto.gov.br/ccivil_03/_ato2011-2014/2011/lei//12462.htm. Acesso em: 10 de julho de 2017.

BRASIL. Lei no 13.105, de 16 de março de 2015. Código de Processo Civil. Diário Oficial da União, Atos do Poder Legislativo, Brasília, DF, de 17/03/2015, p. 01. Disponível em: http://www.planalto.gov.br/ccivil_03/_ato2015-2018/2015/lei/13105.htm. Acesso em: 10 de julho de 2017.

BRASIL. Lei no 13.129, de 26 de maio de 2015. Altera a Lei no 9.307, de 23 de setembro de 1996, e a Lei o 6.404, de 15 de dezembro de 1976, para ampliar o âmbito de aplicação da arbitragem e dispor sobre a escolha dos árbitros quando as partes recorrem a órgão arbitral, a interrupção da prescrição pela instituição da arbitragem, a concessão de tutelas cautelares e de urgência nos casos de arbitragem, a carta arbitral e a sentença arbitral, e revoga dispositivos da Lei № 9.307, de 23 de setembro de 1996. Diário Oficial da União, Atos do Poder Legislativo, Brasília, DF, de 27/05/2015, p. 1. Disponível em: http://www.planalto.gov.br/ccivil_03/_Ato2015-2018/2015/Lei/L13129.htm. Acesso em: 10 de julho de 2017.

BRASIL. Lei no 13.140, de 26 de junho de 2015. Dispõe sobre a mediação entre particulares como meio de solução de controvérsias e sobre a autocomposição de conflitos no âmbito da Administração Pública; altera a Lei oㅜ 9.469, de 10 de julho de 1997, e o Decreto no 70.235, de 6 de março de 1972; e revoga $\circ \S 2^{\circ}$ do art. $6^{\circ}$ da Lei ํㅜ 9.469 , de 10 de julho de 1997. Diário Oficial da União, Atos do Poder Legislativo, Brasília, DF, de 20/06/2015, p. 4. Disponível em: http://www.planalto.gov.br/ccivil_03/_ato2015-2018/2015/Lei/L13140.htm. Acesso em: 10 de julho de 2017.

BRASIL. Lei no 13.448, de 5 de junho de 2017. Estabelece diretrizes gerais para prorrogação e relicitação dos contratos de parceria definidos nos termos da Lei ํㅜ 13.334 , de 13 de setembro de 2016, nos setores rodoviário, ferroviário e aeroportuário da administração pública federal, e altera a Lei no 10.233, de 5 de junho de 2001, e a Lei no 8.987, de 13 de fevereiro de 1995. Diário Oficial da União, Atos do Poder Legislativo, Brasília, DF, de 06/06/2017, p. 1. Disponível em: http://www.planalto.gov.br/ccivil_03/_ato2015-2018/2017/lei/L13448.htm. Acesso em: 10 de julho de 2017. 
CAHALI, Francisco José. Curso de Arbitragem: Mediação, Conciliação, Resolução CNJ 125/2010. 5. ed. rev. e atual. São Paulo: Revista dos Tribunais, 2015.

CÂMARA DE COMÉRCIO INTERNACIONAL (CCI). ICC lança escritório da Corte Internacional de Arbitragem em São Paulo durante Brazilian Arbitration Day, 2017. Disponível em: http://www.iccbrasil.org/noticias/2017/5/8/ICC-lanca-escritorio-da-corte-durante-bad/\#. Acesso em: 02 de julho de 2017.

CAPELLETTI, Mauro; GARTH, Bryant. Acesso à Justiça. trad. e rev. Ellen Gracie Northfleet. Porto Alegre: Sergio Antonio Fabris, 1998.

CARVALHO FILHO, José dos Santos. Manual de Direito Administrativo. 25. ed. rev., ampl. e atual. São Paulo: Atlas, 2012.

CATARINO, João Ricardo. Arbitragem no Direito Tributário: Um estudo de direito comparado sobre a sua admissibilidade e limites em Portugal e no Brasil, Revista de Finanças Públicas e Direito Fiscal, do Instituto de Estudos Financeiros e Fiscais, Faculdade de Direito de Lisboa, Ano V, no 2, 2012.

CATARINO, João Ricardo. Considerações acerca da utilização da arbitragem no direito tributário. Revista Brasileira de Direito Tributário e Finanças Públicas, LexMagister, Vol. 5, p. 164188, jan./fev. Porto Alegre, 2012.

CATARINO, João Ricardo, ROSSINI. Guilherme de Mello, A transação tributária e o mito da (in)disponibilidade dos interesses fazendários, Brasília: Revista da AGU, vol. 15, n. 2, abr./jun. 2016.

CATARINO, João Ricardo, FILLIPO, Luciano Gomes, L'arbitrage dans le droit fiscal, etat actuel et perspectives, publicado em castelhano, italiano e francês, Del Derecho de la Hacienda Pública al Derecho Tributario, Estudios de honor a Andrea Amatucci, Themis, Bogotá e Jovene editore, Nápoles, 2011, pp. $613-645$.

CATARINO, João Ricardo, Para Uma Teoria Política do Tributo, 2. ${ }^{a}$ ed. Cadernos de CTF, Lisboa, Ministério das Finanças, 2009.

COMITÊ BRASILEIRO DE ARBITRAGEM (CBAr). I Jornada Prevenção e Solução Extrajudicial de Litígios. Luis Felipe Salomão, Brasília: CNJ, 2016. Disponível em: http://cbar.org.br/site/wpcontent/uploads/2016/09/Enunciados_I_Jornada.pdf. Acesso em: 10 de julho de 2017.

CONSELHO NACIONAL DE JUSTIÇA (CNJ). Justiça em números 2016: ano-base 2015/Conselho Nacional de Justiça - Brasília: CNJ, 2016.

CONSELHO NACIONAL DE JUSTIÇA. Resolução no 125, de 29 de novembro de 2010. Dispõe sobre a Política Judiciária Nacional de tratamento adequado dos conflitos de interesses no âmbito do Poder Judiciário e dá outras providências. Atos Administrativos, Brasília, DF. Disponível em: http://www.cnj.jus.br/busca-atos-adm?documento=2579. Acesso em: 10 de julho de 2017.

DA ROS, Luciano. 2015. O custo da Justiça no Brasil: uma análise comparativa exploratória. Newsletter. Observatório de elites políticas e sociais do Brasil. NUSP/UFPR, v.2, n. 9, julho. p. 115. ISSN 2359-2826.

DOMINGOS, Francisco Nicolau. Os Métodos Alternativos de Resolução de Conflitos Tributários: Novas tendências dogmáticas. Porto Alegre: Núria Fabris, 2016. 
ENTELMAN, Reno F. Teoría de Conflictos. Barcelona: Gedisa, 2005.

FICHTNER, José Antônio; Sergio Nelson, MANNHEIMER, André Luís, MONTEIRO. Princípios processuais fundamentais aplicáveis à arbitragem brasileira. In: FICHTNER, José Antônio; Sergio Nelson, MANNHEIMER, André Luís, MONTEIRO. Novos Temas de Arbitragem. Rio de Janeiro: FGV, 2014.

GALTUNG, Johan. Transcender e transformar: uma introdução ao trabalho de conflitos. São Paulo: Palas Athena. 2006.

GRECO, Marco Aurélio. Do poder à função tributária. In: ALLEMAND, Luiz Cláudio Silva (COORD.). Direito tributário: questões atuais. Brasília: $O A B$, Conselho Federal, Comissão Especial de Direito Tributário, 2012.

GRINOVER, Ada Pellegrini. Ensaios sobre a processualidade: fundamentos para uma nova teoria geral do processo. São Paulo: Gazeta Jurídica, 2016.

INSTITUTO BRASILEIRO DE PLANEJAMENTO E TRIBUTAÇÃO (IBPT). Quantidade de normas editadas no Brasil: 27 anos da Constituição Federal de 1998, out. 2015. Disponível em: https://www.ibpt.com.br/img/uploads/novelty/estudo/2272/QuantidadeDeNormas201527AnosCF01102 015.pdf. Acesso em: 12 de janeiro de 2017.

Estudo sobre os dias trabalhados para pagar tributos, mai. 2016. Disponível em: https://www.ibpt.com.br/img/uploads/novelty/estudo/2465/DIASTRABALHADOS2016.pdf. Acesso em: 12 de janeiro de 2017.

JUSTEN FILHO, Marçal. Curso de Direito Administrativo. 7. ed. Belo Horizonte: Fórum, 2011.

MARTINS, Ives Gandra da Silva (coord.). Curso do Direito Tributário. 10. ed. rev. e atual. São Paulo: Saraiva, 2008.

MAUS, Ingeborg. Judiciário como Superego da Sociedade: o papel da atividade jurisprudencial na "sociedade órfã". Novos Estudos: CEBRAP, n 58, novembro de 2000.

MEIRELLES, Hely Lopes. Direito Administrativo Brasileiro. 37. ed. atual. até a Emenda Constitucional 67, de 22.12.2010. Eurico de Andrade Azevedo, Délcio Balestero Aleixo, José Emmanuel Burle Filho. São Paulo: Malheiros, 2011.

MOORE, Christopher W. O Processo da Mediação: Estratégias práticas para a resolução de conflitos; trad. Magda França Lopes. 2. ed. Porto Alegre: Artmed, 1998.

MORAIS, Carlos Yuri Araujo. Transação e arbitragem em matéria tributária. In WALD, Arnold. Doutrinas essenciais arbitragem e mediação. São Paulo: Editora Revista dos Tribunais, v. IV, 2014.

ROUSSEAU, Jean-Jacques. Do Contrato Social. trad. Ana Resende. São Paulo: Martin Claret, 2013. SANTANNA, Ana Carolina Squadri. A cultura da sentença. In: Seminário Internacional de Mediação de Conflitos e Justiça Restaurativa. Universidade de Santa Cruz do Sul, 2013. Disponível em: <http://online.unisc.br/acadnet/anais/index.php/mediacao_e_jr/article/view/10862/1393> Acesso em: 01 de julho de 2017.

SOUSA, Jorge Lopes de. Comentário ao Regime Jurídico da Arbitragem Tributária. In: VILLALOBOS, Nuno; VIEIRA, Mónica Brito (COORD.). Guia da Arbitragem Tributária. Coimbra: Almedina, 2013.

Revista do Direito [ISSN 1982-9957]. Santa Cruz do Sul, v. 1, n. 54, p. 59-85, jan./abr. 2018. https://online.unisc.br/seer/index.php/direito/index 
POZZATTI JUNIOR, Ademar; MAILLART, Adriana Silva; SANTOS, Ricardo Soares Stersi dos. Reflexões sobre o ensino dos meios alternativos de resolução de conflitos nos Cursos de Direito. In: MUNIZ, Tânia Lobo; ARAUJO JUNIOR, Miguel Etinger de (ORG.). Estudos em direito negocial e os mecanismos contemporâneos de resolução de conflitos. 1. ed. Birigüi: Boreal Editora, 2014.

TALAMINI, Eduardo; JUSTEN, Mônica Spezia (COORD.). Parcerias Público-Privadas: um enfoque multidisciplinar. São Paulo: Revista dos Tribunais, 2005.

THE ECONOMIST. The past is epilogue, Feb 8th 2014. Disponível em: https://www.economist.com/news/finance-and-economics/21595940-row-over-25-year-old-accountadjustments-unnerves-brazilian-lenders-past. Acesso: em: 03 de julho de 2017.

WATANABE, Kazuo. Cultura da sentença e cultura da pacificação. In: YARSHELL, Flavio Luiz; MORAES, Mauricio Zanoide de (ORG). Estudos em Homenagem à Professora Ada Pellegrini Grinover. São Paulo, DPJ, 2005.

A mentalidade e os meios alternativos de solução de conflitos no Brasil. In: GRINOVER, Ada Pelegrini; WATANABE, Kazuo; LAGRASTA NETO, Caetano. Mediação e gerenciamento do processo. São Paulo: Editora Atlas, 2007.

WEBER, Max. Economia e Sociedade: fundamentos da sociologia compreensiva. trad. Regis Barbosa e Karen Elsabe Barbosa. 4. ed. Brasília: UnB, 2015.

WOLKMER, Antônio Carlos. Pluralismo Jurídico: Fundamentos de uma nova cultura no Direito. 3. ed. rev. e atual. São Paulo: Alfa Ômega, 2001.

ZAVARIZI, Índio Jorge. A Fiscalidade no Brasil República. pp. 123-135. In BALTHAZAR, Ubaldo Cesar (org.). O Tributo na História: Da Antiguidade à Globalização. Florianópolis: Fundação Boiteux, 2006.

\section{COMO CITAR ESSE DOCUMENTO:}

MACHADO, Carlos Henrique; SANTOS, Ricardo Soares Stersi dos; CATARINO, João Ricardo. A arbitrabilidade objetiva dos conflitos envolvendo o poder público e as perspectivas da arbitragem tributária no Brasil. Revista do Direito, Santa Cruz do Sul, v. 1, n. 54, p. 59-85, jun. 2018. ISSN 19829957. Disponível em: <https://online.unisc.br/seer/index.php/direito/article/view/11278>. Acesso em: doi:http://dx.doi.org/10.17058/rdunisc.v1i54.11278. 